\title{
Sensitive and rapid titrimetric and spectrophotometric methods for the determination of stavudine in pharmaceuticals using bromate-bromide and three dyes
}

\author{
KANAKAPURA BASAVAIAH ${ }^{1}$, VEERAIAH RAMAKRISHNA ${ }^{2}$, CHIKKASWAMY SOMASHEKAR ${ }^{1}$ \\ and URDIGERE R. ANIL KUMAR ${ }^{1}$ \\ ${ }^{1}$ Department of Chemistry, University of Mysore, Manasagangotri, Mysore, 570006, India \\ ${ }^{2}$ Department of Drugs Control, Government College of Pharmacy, Bangalore, 560027, India \\ Manuscript received on November 1, 2006; accepted for publication on September 5, 2007; \\ presented by FERNANDO GALEMBECK
}

\begin{abstract}
Four sensitive and rapid methods for the determination of stavudine (STV) in bulk drug and in dosage forms were developed and optimized. In titrimetry, aqueous solution of STV was treated with a known excess of bromate-bromide in $\mathrm{HCl}$ medium followed by estimation of unreacted bromine by iodometric back titration. Spectrophotometric methods involve the addition of a measured excess of bromate-bromide in $\mathrm{HCl}$ medium and subsequent estimation of the residual bromine by reacting with a fixed amount of methyl orange, indigocarmine or thymol blue followed by measurement of absorbance at $520 \mathrm{~nm}(\operatorname{method} \mathrm{A}), 610 \mathrm{~nm}(\operatorname{method} \mathrm{B})$ or $550 \mathrm{~nm}(\operatorname{method} \mathrm{C})$. In all the methods, the amount of bromate reacted corresponds to the amount of STV. Calculations in titrimetry were based on a 1:0.666 $\left(\mathrm{STV}: \mathrm{KBrO}_{3}\right)$ stoichiometry and the method was found to be applicable over $3.5-10 \mathrm{mg}$ range. A linear increase in absorbance with concentration of STV was observed in the spectrophotometric methods, and the Beer's law was obeyed over the concentration ranges $0.125-1.75,1-10$ and 1-9.0 $\mu \mathrm{g} \mathrm{mL}^{-1} \mathrm{STV}$ for method A, method B and method C, respectively. The methods when applied to the determination of STV in tablets and capsules were found to give satisfactory results.
\end{abstract}

Key words: Stavudine determination, titrimetry, spectrophotometry, bromate-bromide, dyes, pharmaceuticals.

\section{INTRODUCTION}

Stavudine (STV), chemically known as $2^{1}-3^{1}$-didehydro$2^{1}-3^{1}$-dideoxythymidine (Fig. 1), is a nucleoside analog reverse transcriptase inhibitor (NARTI) active against HIV (The Merck Index 1996). STV is converted intracellularly to triphosphate which stops the DNA synthesis of retroviruses through competitive inhibition of reverse transcriptase and incorporation into viral DNA. It is the fourth antiretroviral drug in the market and is used in the treatment of HIV infection. The drug is official in United States of Pharmacopoeia (The United States Pharmacopoeia 2006). which describes high performance liquid chromatography as assay procedures for bulk drug and tablets, respectively.

Correspondence to: Basavaiah K.

E-mail: basavaiahk@yahoo.co.in
A number of methods based on high performance liquid chromatography (Bazy et al. 2005, Verweij-van Wissen et al. 2005, Contreras et al. 2004), liquid chromatography-tandem mass spectrometry (Compain et al. 2005, Huang et al. 2004, Raices et al. 2003, Fan et al. 2002, Wiesner et al. 2002), micellar electrokinetic chromatography (Fan and Stewart 2002), radio immuno assay (Tran et al. 2003) and electrophoresis (Pereira et al. 2005) are known for the quantitative determination of STV in biological matrices such as blood plasma, blood serum and human cells. Several chromatographic techniques including HPLC (Dunge et al. 2005, Djurdjevic et al. 2004, Zhang et al. 2003, Sablon et al. 2004, Pai and Desai 2003, Rezk et al. 2003), HPTLC (Wankhede et al. 2005, Kaul et al. 2005) and LC-MS (Volosov et al. 2002), have been used for the determi- 
nation of STV in pharmaceuticals. The drug has also been assayed by mass spectrometry (Soldin 2004) and UV-spectrophotometry (Sankar et al. 2002a).

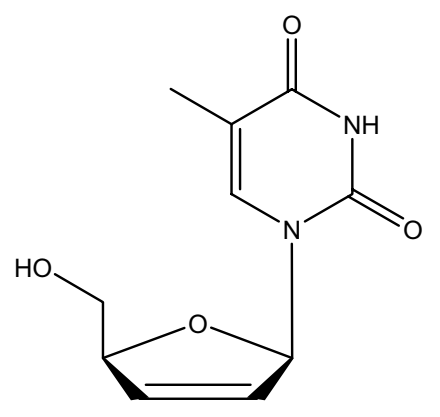

Fig. 1 - Structure of drug.

Despite its long history and established versatility, no titrimetric method has yet been reported for the determination of STV in pharmaceuticals. Visible spectrophotometry, because of its simplicity, speed, sensitivity, reasonable accuracy and precision, and cost-effectiveness, continues to be the preferred technique in laboratories of developing and underdeveloped nations, which can illafford expensive chromatographic and related techniques. Three procedures (Sarma et al. 2002a) have been reported for the assay of STV in pharmaceuticals using $\mathrm{KMnO}_{4}$-Fast green $\mathrm{FCF}$, permanganate/periodateMBTH and iron(III)chloride-ferricyanide as reagents. The same authors (2002b) have used three more reagents, NBS-celestine blue, cobalt thiocyanate and ammonium molybdate for the spectrophotometric determination of STV. A method based on oxidative-coupling reaction (Sankar et al. 2002b) involving the use of iron (III)MBTH is also found in the literature. But, these methods suffer from one or the other disadvantage like poor sensitivity, heating or extraction step and/or use of expensive chemical/organic solvent.

This paper reports the use of bromate-bromide reagent and three dyes-methyl orange, indigocarmine and thymol blue for rapid and sensitive determination of STV. The methods are based on the bromination/oxidation of the drug by in situ generated bromine followed by estimation of residual bromine by either iodometric back titration or by reacting with a fixed quantity of dye and measuring the change in absorbance. The methods on applying to tablets and capsules yielded satisfactory results and were comparable with those of a reference method.

\section{MATERIALS AND METHODS}

Apparatus: A Systronics Model 106 digital spectrophotometer provided with matched 1-cm quartz cells was used for all absorbance measurements. All chemicals used were of analytical reagent grade and distilled water was used to prepare all solutions.

Reagents and standards: Bromate-bromide mixture $\left(4 \mathrm{mmol} \mathrm{L}{ }^{-1} \mathrm{KBrO}_{3}-40 \times 10^{-3} \mathrm{mmol} \mathrm{L}^{-1} \mathrm{KBr}\right.$ ) was prepared by dissolving accurately weighed $0.668 \mathrm{~g}$ of $\mathrm{KBrO}_{3}$ (Sarabhai M Chemicals, Baroda, India) and $4.76 \mathrm{~g}$ of $\mathrm{KBr}$ (Indian Drugs and Pharmaceuticals Ltd, Hydrabad, India) in water and diluting to 1 litre in a calibrated flask, and the reagent was used in titrimetric work. A $0.024 \mathrm{~mol} \mathrm{~L}^{-1}$ sodium thiosulphate solution was prepared by dissolving about $5.96 \mathrm{~g}$ of chemical (Sisco Chem. Industries, Mumbai, India) in 1 litre of water. A $10 \%$ potassium iodide solution was prepared by dissolving $10 \mathrm{~g}$ of salt (Merck Chemicals, Mumbai, India) in $100 \mathrm{~mL}$ of water. To prepare $1 \%$ starch indicator, $1 \mathrm{~g}$ of soluble starch (S.d. Fine Chem., Mumbai, India) was made into paste in water and poured into $100 \mathrm{~mL}$ boiling water, boiled for $1 \mathrm{~min}$ and cooled. For spectrophotometric investigations, a bromate-bromide solution equivalent $1000 \mu \mathrm{g} \mathrm{mL}^{-1} \mathrm{KBrO}_{3}$ and 10 - fold excess of $\mathrm{KBr}$ was prepared by dissolving accurately weighed $100 \mathrm{mg}$ of $\mathrm{KBrO}_{3}$ and $1 \mathrm{~g}$ of $\mathrm{KBr}$ in water and diluting to the mark in a $100 \mathrm{~mL}$ calibrated flask. This was then diluted stepwise to obtain working concentrations of 10,30 and $50 \mu \mathrm{g} \mathrm{mL}^{-1} \mathrm{KBrO}_{3}$ for use in method $\mathrm{A}$, method $\mathrm{B}$ and method $\mathrm{C}$, respectively. Concentrated hydrochloric acid (S.D. Fine Chem., Mumbai, India; sp. gr. 1.18) was diluted appropriately with water to get $5 \mathrm{~mol}$ $\mathrm{L}^{-1}$ for spectrophotometric work and it was diluted to get $2 \mathrm{~mol} \mathrm{~L}^{-1}$ for titrimetry. A $500 \mu \mathrm{g} \mathrm{mL}^{-1}$ methyl orange dye solution was first prepared by dissolving accurately weighed $58.8 \mathrm{mg}$ of dye (S.D. Fine Chem., Mumbai, India, assay $85 \%$ ) in water and diluting to $100 \mathrm{~mL}$ in a calibrated flask and filtered using glass wool. It was further diluted to obtain a working concentration of $50 \mu \mathrm{g} \mathrm{mL}^{-1}$. A stock standard solution equivalent to $1000 \mu \mathrm{g} \mathrm{mL}^{-1}$ indigo carmine was first prepared by dissolving accurately weighed $112 \mathrm{mg}$ of dye (S.D. Fine Chem., Mumbai, India, $90 \%$ dye content) in water and diluting to volume in a $100 \mathrm{~mL}$ calibrated flask. The solution was then diluted 5fold to get the working concentration of $200 \mu \mathrm{g} \mathrm{mL}^{-1}$. A 
$1000 \mu \mathrm{g} \mathrm{mL}^{-1}$ stock standard solution of thymol blue was first prepared by dissolving accurately weighed $100 \mathrm{mg}$ of dye (Loba. Chemie. Mumbai. India, 100\% dye content) in water and diluting to volume in a $100 \mathrm{~mL}$ calibrated flask. The solution was then diluted five fold to get the working concentration of $200 \mu \mathrm{g} \mathrm{mL}^{-1}$.

Standard drug solution: Pharmaceutical grade STV was received from Cipla India Ltd., (99.8\% pure), as gift and was used as received. A stock standard solution containing $1 \mathrm{mg} \mathrm{mL}^{-1} \mathrm{STV}$ was prepared by dissolving accurately weighed $250 \mathrm{mg}$ of pure drug in water and diluting to the mark in a $250 \mathrm{~mL}$ calibrated flask. This solution was used for titrimetric work, and for spectrophotometric work, the same was diluted appropriately with water to get a working concentration of $5 \mu \mathrm{g} \mathrm{mL}^{-1}$ for method A, and 20 and $40 \mu \mathrm{g} \mathrm{mL}^{-1}$ for method B and method $\mathrm{C}$, respectively.

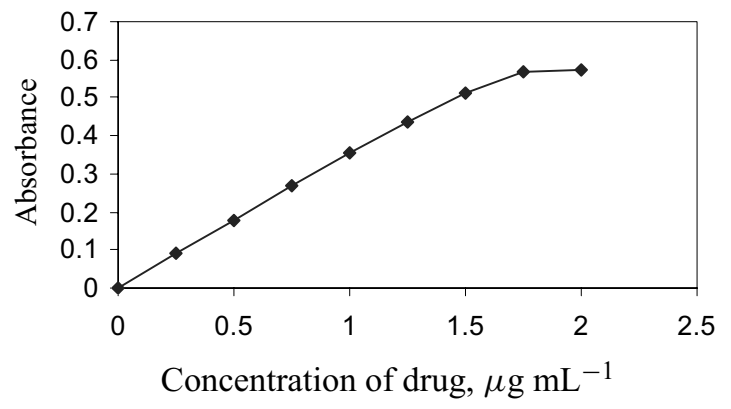

Fig. 2 - Beer's law curve for method A.

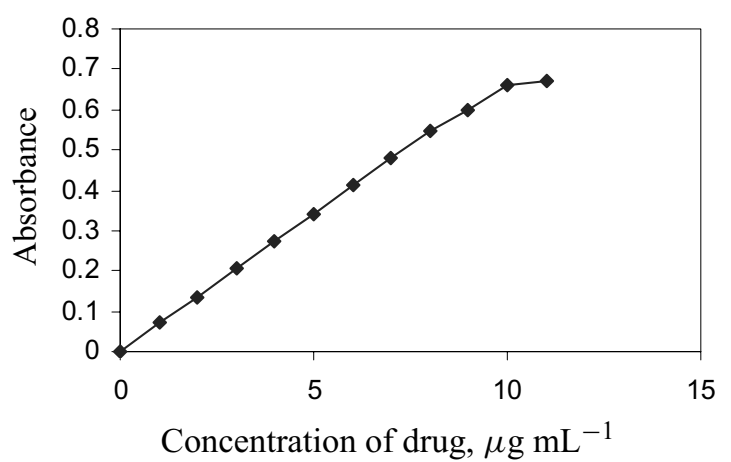

Fig. 3 - Beer's law curve for method B.

\section{Procedures}

Titrimetry: A $10 \mathrm{~mL}$ aliquot of pure drug solution containing 3.5-10 mg of STV was accurately measured and

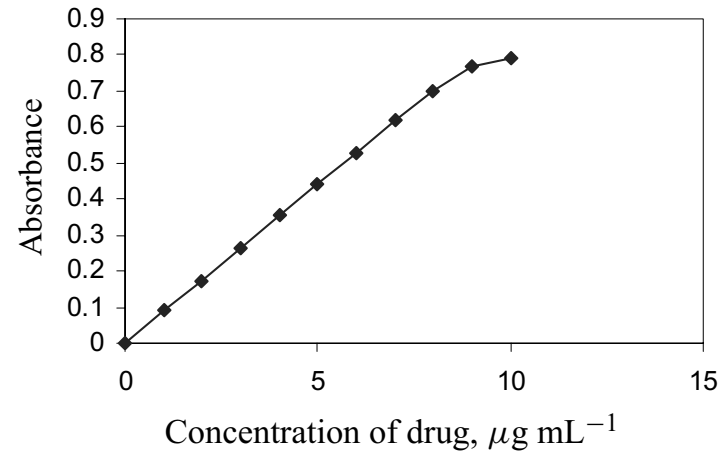

Fig. 4 - Beer's law curve for method C.

transferred into a $100 \mathrm{~mL}$ Erlenmeyer flask. The solution was acidified by adding $3 \mathrm{~mL}$ of $2 \mathrm{~mol} \mathrm{~L}^{-1}$ hydrochloric acid and diluted to $15 \mathrm{~mL}$ with water. Ten $\mathrm{mL}$ of bromate-bromide reagent $\left(4 \mathrm{mmol} \mathrm{L}^{-1}\right.$ w.r.t. $\left.\mathrm{KBrO}_{3}\right)$ was pipetted into the flask, the flask was stoppered, the contents mixed and let stand for $10 \mathrm{~min}$ with occasional swirling. Finally, $5 \mathrm{~mL}$ of $10 \%$ potassium iodide solution was added, and the liberated iodine was titrated against $0.024 \mathrm{~mol} \mathrm{~L}^{-1}$ thiosulphate solution using starch as indicator towards the end point. A blank titration was performed, and the amount of drug in the measured aliquot was calculated from the amount of $\mathrm{KBrO}_{3}$ reacted with drug.

Spectrophotometric method A: Different aliquots $(0.25,1.0,1.5, \ldots 3.5 \mathrm{~mL})$ of a standard $5 \mu \mathrm{g} \mathrm{mL}-1$ STV solution were transferred into a series of $10 \mathrm{~mL}$ calibrated flasks by means of a micro burette and the total volume was adjusted to $4 \mathrm{~mL}$ by adding adequate quantity of water. To each flask were added $1 \mathrm{~mL}$ each of $5 \mathrm{~mol} \mathrm{~L}^{-1} \mathrm{HCl}$ and bromate-bromide solution (10 $\mu \mathrm{g} \mathrm{mL}^{-1}$ in $\mathrm{KBrO}_{3}$ ), the last being measured accurately. The flasks were stoppered, content mixed and let stand for $20 \mathrm{~min}$ with occasional shaking. Finally, $1 \mathrm{~mL}$ of $50 \mu \mathrm{g} \mathrm{mL}^{-1}$ methyl orange solution was added (accurately measured) and the volume was diluted to the mark with water and mixed well. The absorbance of each solution was measured at $510 \mathrm{~nm}$ against a reagent blank after $5 \mathrm{~min}$.

Spectrophotometric method B: Varying aliquots $(0.5,1.0, \ldots 5.0 \mathrm{~mL})$ of a standard $20 \mu \mathrm{g} \mathrm{mL}{ }^{-1} \mathrm{STV}$ solution were transferred into a series of $10 \mathrm{~mL}$ calibrated flasks by means of a micro burette and the total 
volume was brought to $5 \mathrm{~mL}$ by adding water. To each flask were added $1 \mathrm{~mL}$ of $5 \mathrm{~mol} \mathrm{~L}^{-1}$ hydrochloric acid and $1.5 \mathrm{~mL}$ of bromate-bromide solution $\left(30 \mu \mathrm{g} \mathrm{mL}^{-1}\right.$ in $\mathrm{KBrO}_{3}$ ) by means of a micro burette. The content was mixed well and the flasks were kept aside for 10 min with intermittent shaking. Finally, $1 \mathrm{~mL}$ of $200 \mu \mathrm{g}$ $\mathrm{mL}^{-1}$ indigo carmine solution was accurately measured and added to each flask, the volume was diluted to the mark with water, mixed well and absorbance measured against a reagent blank at $610 \mathrm{~nm}$ after $5 \mathrm{~min}$.

Spectrophotometric method C: Different aliquots $(0.25,0.5,1.0, \ldots 2.25 \mathrm{~mL})$ of a standard $40 \mu \mathrm{g} \mathrm{mL}^{-1}$ STV solution were transferred into a series of $10 \mathrm{~mL}$ calibrated flasks by means of a micro burette and the total volume was adjusted to $3 \mathrm{~mL}$ by adding adequate quantity of water. To each flask were added $1 \mathrm{~mL}$ each of $5 \mathrm{~mol} \mathrm{~L}^{-1} \mathrm{HCl}$ and bromate-bromide solution (50 $\mu \mathrm{g} \mathrm{mL}^{-1}$ in $\mathrm{KBrO}_{3}$ ), the last being measured accurately. The flasks were stoppered, content mixed and let stand for $15 \mathrm{~min}$ with occasional shaking. Finally, $1 \mathrm{~mL}$ of $200 \mu \mathrm{g} \mathrm{mL}^{-1}$ thymol blue solution was added (accurately measured) and the volume was diluted to the mark with water and mixed well. The absorbance of each solution was measured at $550 \mathrm{~nm}$ against a reagent blank after $5 \mathrm{~min}$.

In all the three spectrophotometric method, a standard graph was prepared by plotting the absorbance versus the concentration of STV. The concentration of the unknown was read from the calibration graph or computed from the regression equation derived using Beer's law data.

\section{PROCEDURE FOR DOSAGE ForMS}

Procedure for tablets/capsule: Twenty tablets/contents of capsules were weighed and ground into a fine powder. An amount of powder equivalent to $250 \mathrm{mg}$ of STV was weighed into a $250 \mathrm{~mL}$ calibrated flask, $60 \mathrm{~mL}$ of water added and the mixture shaken for $20 \mathrm{~min}$; then the volume was made up to the mark with water, mixed well and filtered using a Whatman No. 42 filter paper. First $10 \mathrm{~mL}$ portion of the filtrate was discarded and a suitable aliquot was then subjected to analysis by titrimetric method. The tablet extract $\left(1 \mathrm{mg} \mathrm{mL}^{-1}\right)$ was diluted suitably with water to get working concentrations of 5, 20 and $40 \mu \mathrm{g} \mathrm{mL}^{-1}$ for method A, method B and method C, respectively before subjecting to analysis by spectrophotometric methods.

\section{RESULTS AND DISCUSSION}

The acidified solution of bromate and bromide behaves as an equivalent solution of bromine and has been widely used for the determination of many organic and inorganic substances. The present methods make use oxidising/brominating ability, and bleaching action of in situ generated bromine on the dyes used.

The proposed spectrophotometric methods are indirect and are based on the determination of the residual bromine (in situ generated) after allowing the reaction between STV and a measured amount of bromine to be complete. The bromine was determined by reacting it with a fixed amount of methyl orange, indigo carmine or thymol blue dye. The methods make use of bleaching action of bromine on the dyes, the decolouration being caused by the oxidative destruction of the dyes.

\section{Method Development}

Titrimetry: Direct titration of STV with in situ generated bromine was not successful. However, the reaction between the two was found to occur when the two were allowed to stand for some time, thus enabling the indirect titrimetric determination of STV. Hence, several factors like nature of acid and its concentration, reaction time, and the excess of reagent were optimized. Reproducible and stoichiometric results were obtained when 0.16 to $0.32 \mathrm{~mol} \mathrm{~L}^{-1}$ hydrochloric acid concentration was maintained. Hence, $0.24 \mathrm{~mol} \mathrm{~L}^{-1}$ acid concentration for the oxidation step and the iodometric back titration was used in the assay. Reaction was complete in $10 \mathrm{~min}$ and yielded stoichiometry of 1:0.666 (STV: $\mathrm{KBrO}_{3}$ ), and contact times up to $20 \mathrm{~min}$ had no effect on the stoichiometry of the reaction. A constant molarratio was obtained when excess of reagent was not more than 2 times the theoretical amount. Under the optimum conditions, 3.5-10 mg of STV could be determined with good accuracy and precision with reaction stoichiometry of 1:0.666.

Spectrophotometry: STV, when added in increasing concentrations to a fixed concentration of in situ generated bromine, consumes the latter proportionally and there occurs a concomitant fall in the concentration of 
bromine. When a fixed concentration of dye is added to decreasing concentrations of bromine, a concomitant increase in the concentration of dye results. Consequently, a proportional increase in the absorbance at the respective $\lambda_{\max }$ is observed with increasing concentration of STV.

Preliminary experiments were performed to fix the upper concentrations of the dyes that could be determined spectrophotometrically, and these were found to be 5, 20 and $20 \mu \mathrm{g} \mathrm{mL}^{-1}$ for methyl orange, indigo carmine and thymol blue respectively. A bromate concentration of $1 \mu \mathrm{g} \mathrm{mL}^{-1}$ in the presence of excess of bromide was found to bleach the red colour due to $5 \mu \mathrm{g} \mathrm{mL}^{-1}$ methyl orange whereas 4.5 and $5.0 \mu \mathrm{g} \mathrm{mL}^{-1}$ bromate was required to destroy the blue and violet colour due to $20 \mu \mathrm{g} \mathrm{mL}^{-1}$ each of indigocarmine and thymol blue, respectively. Hence, different concentrations of STV were reacted with $1 \mathrm{~mL}$ of $10 \mu \mathrm{g} \mathrm{mL}^{-1} \mathrm{KBrO}_{3}$ in method $\mathrm{A}, 1.5 \mathrm{~mL}$ of $30 \mu \mathrm{g} \mathrm{mL}^{-1} \mathrm{KBrO}_{3}$ in method $\mathrm{B}$ and $1 \mathrm{~mL}$ of $50 \mu \mathrm{g} \mathrm{mL}^{-1} \mathrm{KBrO}_{3}$ in method $\mathrm{C}$ respectively, followed by determination of residual bromine as described under the respective procedure.

For both steps, i.e., the reaction between STV and bromine, and the determination of the latter by reacting with the dye, $\mathrm{HCl}$ medium was found to be ideally suited. One $\mathrm{mL}$ of $5 \mathrm{~mol} \mathrm{~L}^{-1}$ acid in a total volume of about 5 $7 \mathrm{~mL}$ was used in all the methods and the same quantity of acid was maintained for the bleaching step. Reaction times of 20, 10 and $15 \mathrm{~min}$ are not critical for method A, method B and method C. respectively, and any delay up to $30 \mathrm{~min}$ did not affect the absorbance reading. A 5 min standing time was found necessary for the complete bleaching of the dye colour by the residual bromine. The absorbance of each dye colour was constant for several hours even in the presence of reaction product.

Analytical data: A linear correlation was found between absorbance at $\lambda_{\max }$ and concentration of STV in the ranges given in Table I. The graphs showed negligible intercept as described by the regression equation:

$$
Y=a+b X
$$

(where $Y=$ absorbance of 1-cm layer of solution; $a$ = intercept; $b=$ slope and $X=$ concentration in $\mu \mathrm{g}$ $\left.\mathrm{mL}^{-1}\right)$. Regression analysis of the Beer's law data using the method of least squares was made to evaluate the slope (b), intercept (a) and correlation coefficient (r) for each system and the values are presented in Table I. The optical characteristics such as Beer's law limits, molar absorptivity and Sandell sensitivity values of all the three methods are also given in Table I. The limits of detection (LOD) and quantitation (LOQ) calculated according to ICH guidelines (ICH Harmonised Triplicate Guideline 1996) are also presented in Table I and reveal the very high sensitivity of the methods.

Method validation: To evaluate the accuracy and intraday precision of the methods, pure drug solution at three different levels (concentrations) was analysed, each determination being repeated seven times. The relative error (\%) and relative standard deviation (\%) were less than 3.0 and indicate high accuracy and precision of the methods (Table III). For a better picture of reproducibility on a day-to-day basis, a series of experiments was performed in which standard drug solution at three different levels was determined each-day for five days with all solutions being prepared afresh each day. The day-to-day relative standard deviation values were in the range of $2.0-3.5 \%$ and represent the best appraisal of repeatability of the proposed methods.

\section{APPLICATION}

Three brands of STV tablets/capsules in 30 and $40 \mathrm{mg}$ strength are currently available in the Indian market. The validity of the methods was checked by applying them to assay in two brands of capsules and one brand of tablets. Table IV gives the results of assay and reveal that there is close agreement between the results obtained by the proposed methods and the label claim. The results were also compared statistically with those obtained by a literature method (Sankar et al. 2002a) by applying Student's t-test for accuracy and F-test for precision. At the 95\% confidence level, the calculated $\mathrm{t}-$ and F-values did not exceed the tabulated values $(\mathrm{t}=2.77$ and $\mathrm{F}=6.39)$ suggesting that the proposed methods are as accurate and precise as the literature method.

The accuracy and validity of the proposed methods were further ascertained by performing recovery experiments. Pre-analysed tablet/capsule powder was spiked with pure STV at three different levels and the total was found by the proposed methods. Each determination was repeated three times. The recovery of pure 
TABLE I

Comparison of performance characteristics of proposed methods with the existing spectrophotometric methods.

\begin{tabular}{|c|c|c|c|c|c|c|}
\hline $\begin{array}{l}\text { Sl } \\
\text { No. }\end{array}$ & Reagent* & $\begin{array}{c}\lambda_{\max }, \\
\mathrm{nm}\end{array}$ & $\begin{array}{c}\text { Linear range, } \\
\mu \mathrm{g} \mathrm{mL}^{-1}\end{array}$ & $\in, \mathrm{L} \mathrm{mol}^{-1} \mathrm{~cm}^{-1}$ & Remarks & Ref. \\
\hline 1. & $\begin{array}{l}\text { a) } \mathrm{KMnO}_{4} \text {-FG FCF } \\
\text { b) } \mathrm{NaIO}_{4}-\mathrm{MBTH} \\
\text { c) Iron (III)-ferricyanide }\end{array}$ & $\begin{array}{l}640 \\
620 \\
740\end{array}$ & $\begin{array}{c}1-8 \\
0.6-6.0 \\
9.0-75.0\end{array}$ & $\begin{array}{l}1.28 \times 10^{4} \\
2.02 \times 10^{4} \\
1.24 \times 10^{3}\end{array}$ & $\begin{array}{l}\text { Uses an oxidant, which } \\
\text { is unstable in solution } \\
\text { Use an expensive chemical }\end{array}$ & Sarma et al. 2002a \\
\hline 2. & $\begin{array}{l}\text { a) NBS-celestine blue } \\
\text { b) Cobalt thiocyante } \\
\text { c) Ammonium molybdate }\end{array}$ & $\begin{array}{l}540 \\
610 \\
700\end{array}$ & $\begin{array}{l}0.7-6.0 \\
1.5-15.0 \\
11-150\end{array}$ & $\begin{array}{l}1.6 \times 10^{4} \\
7.7 \times 10^{3} \\
1.0 \times 10^{3}\end{array}$ & $\begin{array}{l}\text { Uses an unstable solution } \\
\text { Involves extraction step } \\
\text { with organic solvent } \\
\text { Requires heating; } \\
\text { least sensitive }\end{array}$ & Sarma et al. $2002 b$ \\
\hline 3. & Iron (III)-MBTH & & & & & Sankar et al. $2002 b$ \\
\hline 4. & $\begin{array}{l}\text { a) } \mathrm{BrO}_{3}^{-}-\mathrm{Br}^{-} \text {-Methyl orange } \\
\text { b) } \mathrm{BrO}_{3}^{-}-\mathrm{Br}^{-} \text {-Indigo carmine } \\
\text { c) } \mathrm{BrO}_{3}^{-}-\mathrm{Br}^{-} \text {-Thymol blue }\end{array}$ & $\begin{array}{l}520 \\
610 \\
550\end{array}$ & $\begin{array}{c}0.125-1.75 \\
1-10 \\
1-9 \\
\end{array}$ & $\begin{array}{l}3.94 \times 10^{4} \\
1.45 \times 10^{4} \\
1.99 \times 10^{4}\end{array}$ & $\begin{array}{l}\text { No heating or } \\
\text { extraction step, uses } \\
\text { stable solution }\end{array}$ & Present methods \\
\hline
\end{tabular}

*FGFCF $=$ Fast green FCF; MBTH = 3-methylbenzothiazolinone hydrazone; NBS = N-bromosuccinimide.

TABLE II

Quantification and regression characteristics of spectrophotometric methods.

\begin{tabular}{l|c|c|c}
\hline Parameter & Method A & Method B & Method C \\
\hline$\lambda_{\max }, \mathrm{nm}$ & 520 & 610 & 550 \\
\hline Beer's law limits, $\mu \mathrm{g} \mathrm{mL}^{-1}$ & $0.125-1.75$ & $1.0-10.0$ & $1.0-9.0$ \\
\hline Molar absorptivity, $\mathrm{L} \mathrm{moL}^{-1} \mathrm{~cm}^{-1}$ & $3.94 \times 10^{4}$ & $1.45 \times 10^{4}$ & $1.99 \times 10^{4}$ \\
\hline Sandell sensitivity, $\mu \mathrm{g} \mathrm{cm}^{-2}$ & 0.0057 & 0.0154 & 0.0112 \\
\hline Limit of detection, $\mu \mathrm{g} \mathrm{mL}^{-1}$ & 0.03 & 0.15 & 0.11 \\
\hline Limit of quantification, $\mu \mathrm{g} \mathrm{mL}^{-1}$ & 0.11 & 0.44 & 0.34 \\
\hline Regression equation, $\mathrm{Y}^{*}$ & & & \\
Intercept (a) Slope (b) & 0.017 & -0.003 & 0.004 \\
Slope (b) & 0.159 & 0.067 & 0.085 \\
\hline Correlation coefficient, $(\mathrm{r})$ & 0.9987 & 0.9997 & 0.9994 \\
$\mathrm{~S}_{\mathrm{a}}$ & 0.00858 & 0.0055 & 0.0218 \\
$\mathrm{~S}_{\mathrm{b}}$ & 0.00324 & 0.0006 & 0.0024 \\
\hline
\end{tabular}

$* \mathrm{Y}=\mathrm{a}+\mathrm{bX}$, where $\mathrm{Y}$ is the absorbance and $\mathrm{X}$ concentration in $\mu \mathrm{g} \mathrm{mL}{ }^{-1} . \mathrm{S}_{\mathrm{a}}=$ Standard deviation of intercept. $\mathrm{S}_{\mathrm{b}}=$ Standard deviation of slope.

drug added was quantitative (97.7-104.2\%) and revealed that co-formulated substances such as talc, starch, gelatin, gum acacia, calcium carbonate, calcium gluconate, calcium dihydrogen orthophosphate, sodium alginate and magnesium stearate did not interfere in the determination.

\section{CONCLUSIONS}

Four useful micro methods for the determination of STV have been developed and validated as per the current ICH guidelines (ICH guidelines, 1996, 2005). The proposed methods are simple, rapid and cost-effective. The methods are one of the most sensitive ever reported 
TABLE III

Intra-day accuracy and precision of the methods.

\begin{tabular}{l|c|c|c|c|c|c|c|c}
\hline \multirow{2}{*}{ Method* } & $\begin{array}{c}\text { STV } \\
\text { taken }\end{array}$ & $\begin{array}{c}\text { STV } \\
\text { found, } * *\end{array}$ & Range & $\begin{array}{c}\text { Relative } \\
\text { error, } \%\end{array}$ & SD & SEM & $\begin{array}{c}\text { RSD, } \\
\%\end{array}$ & CL \\
\hline \multirow{3}{*}{ Titrimetry } & 4.0 & 3.93 & 0.14 & 1.75 & 0.033 & 0.013 & 0.84 & $3.93 \pm 0.031$ \\
\cline { 2 - 9 } & 6.0 & 5.85 & 0.18 & 2.50 & 0.134 & 0.051 & 2.29 & $5.85 \pm 0.124$ \\
\cline { 2 - 9 } & 9.0 & 8.82 & 0.12 & 2.00 & 0.054 & 0.020 & 0.61 & $8.82 \pm 0.049$ \\
\hline \multirow{2}{*}{$\begin{array}{l}\text { Spectro- } \\
\text { photometric } \\
\text { method A }\end{array}$} & 0.5 & 0.49 & 0.07 & 1.70 & 0.005 & 0.002 & 0.96 & $0.49 \pm 0.010$ \\
\cline { 2 - 9 } & 1.0 & 0.98 & 0.05 & 1.48 & 0.008 & 0.003 & 0.85 & $0.98 \pm 0.021$ \\
\hline \multirow{2}{*}{$\begin{array}{l}\text { Spectro- } \\
\text { photometric } \\
\text { method B }\end{array}$} & 1.5 & 1.47 & 0.07 & 1.45 & 0.017 & 0.006 & 1.14 & $1.47 \pm 0.025$ \\
\cline { 2 - 9 } & 3.0 & 2.93 & 0.07 & 2.33 & 0.033 & 0.013 & 1.13 & $2.93 \pm 0.031$ \\
\hline \multirow{2}{*}{$\begin{array}{l}\text { Spectro- } \\
\text { photometric } \\
\text { method C }\end{array}$} & 9.0 & 5.85 & 0.05 & 2.45 & 0.064 & 0.024 & 1.09 & $5.85 \pm 0.059$ \\
\cline { 2 - 9 } & 4.0 & 1.95 & 0.07 & 2.50 & 0.029 & 0.011 & 1.49 & $1.95 \pm 0.027$ \\
\hline
\end{tabular}

*In titrimetry taken/found/range, SD and SEM are in mg while in spectrophotometric methods the they are in $\mu \mathrm{g} \mathrm{mL}^{-1}$. **Mean value of seven determinations $\mathrm{SD}=$ Standard deviation; $\mathrm{SEM}=$ Standard mean of error; $\mathrm{RSD}=$ Relative standard deviation; and $\mathrm{CL}=$ Confidence limits at 95\% confidence level for six degrees of freedom.

TABLE IV

Results of assay of STV in dosage forms by proposed methods and statistical comparision with reference method.

\begin{tabular}{|c|c|c|c|c|c|c|}
\hline \multirow{3}{*}{$\begin{array}{c}\text { Dosage form } \\
\text { and brand } \\
\text { name* }\end{array}$} & \multirow{3}{*}{$\begin{array}{l}\text { Nominal } \\
\text { amount, } \\
\text { mg per } \\
\text { tablet/ }\end{array}$} & \multicolumn{5}{|c|}{$\%$ Found $\Psi \pm$ SD } \\
\hline & & \multirow[b]{2}{*}{$\begin{array}{l}\text { Reference } \\
\text { Methods }\end{array}$} & \multirow[b]{2}{*}{ Titrimetry } & \multicolumn{3}{|c|}{ Spectrophotometry } \\
\hline & & & & $\begin{array}{c}\text { Method } \\
\text { A }\end{array}$ & $\begin{array}{l}\text { Method } \\
\text { B }\end{array}$ & $\begin{array}{c}\text { Method } \\
\text { C }\end{array}$ \\
\hline \multicolumn{7}{|l|}{ Capsule } \\
\hline \multirow[t]{3}{*}{$\mathrm{STAG}^{\mathrm{a}}$} & 30 & $102.3 \pm 0.96$ & $100.9 \pm 1.51$ & $101.1 \pm 1.42$ & $100.5 \pm 1.51$ & $101.3 \pm 1.46$ \\
\hline & & & $\mathrm{t}=1.79$ & $\mathrm{t}=2.31$ & $\mathrm{t}=1.59$ & $\mathrm{t}=1.31$ \\
\hline & & & $F=2.47$ & $F=2.19$ & $F=2.44$ & $\mathrm{~F}=2.31$ \\
\hline \multirow[t]{3}{*}{ STAVIR $^{b}$} & 40 & $98.54 \pm 1.24$ & $99.8 \pm 1.79$ & $99.7 \pm 1.98$ & $101.1 \pm 1.85$ & $100.7 \pm 1.95$ \\
\hline & & & $\mathrm{t}=1.31$ & $\mathrm{t}=1.33$ & $t=2.62$ & $\mathrm{t}=2.14$ \\
\hline & & & $F=2.08$ & $F=2.55$ & $F=2.23$ & $F=2.47$ \\
\hline \multicolumn{7}{|l|}{ Tablets } \\
\hline \multirow[t]{3}{*}{ VIROSTAV } & 30 & $101.3 \pm 0.62$ & $100.9 \pm 1.25$ & $99.9 \pm 1.42$ & $102.9 \pm 1.21$ & $102.4 \pm 1.42$ \\
\hline & & & $\mathrm{t}=0.68$ & $\mathrm{t}=2.17$ & $t=2.76$ & $\mathrm{t}=1.70$ \\
\hline & & & $F=4.06$ & $F=5.25$ & $\mathrm{~F}=3.81$ & $F=5.25$ \\
\hline
\end{tabular}

*Marked by: $\mathrm{a}=$ Cross lands; $\mathrm{b}=$ Cipla India Ltd; $\mathrm{c}=$ Genix Pharm. India. $\Psi=$ Mean value of five determinations. Tabulated value of $\mathrm{t}$ at $95 \%$ confidence level is 2.77 and tabulated F-value at the same level confidence is 6.39 both for four degrees of freedom. 
TABLE V

Results of recovery study via standard-addition method.

\begin{tabular}{l|c|c|c|c|c}
\hline Method & $\begin{array}{c}\text { Tablet } \\
\text { studied }\end{array}$ & $\begin{array}{c}\text { STV in } \\
\text { formulation }\end{array}$ & $\begin{array}{c}\text { Pure STV } \\
\text { added }\end{array}$ & $\begin{array}{c}\text { Total } \\
\text { found }\end{array}$ & $\begin{array}{c}\text { Pure STV } \\
\text { recovered*, \% }\end{array}$ \\
\hline & VIROSTAV & 3.03 & 2.0 & 5.08 & 102.5 \\
Titrimetry & 30 & 3.03 & 4.0 & 7.08 & 101.2 \\
& & 3.03 & 6.0 & 8.95 & 98.6 \\
\hline Spectro- & & 5.00 & 3.0 & 8.08 & 102.5 \\
photometric & & 5.00 & 7.0 & 12.08 & 101.2 \\
method A & & 5.00 & 9.0 & 13.87 & 98.6 \\
\hline Spectro- & & 20.58 & 20.0 & 40.52 & 99.7 \\
photometric & & 20.58 & 40.0 & 59.90 & 98.3 \\
method B & & 20.58 & 80.0 & 101.06 & 100.6 \\
\hline Spectro- & & 10.24 & 20.0 & 30.88 & 103.2 \\
photometric & & 10.24 & 40.0 & 49.52 & 98.2 \\
method C & & 10.24 & 80.0 & 90.64 & 100.5 \\
\hline
\end{tabular}

* Mean value of three determinations. In titrimetry STV in dosage form/pure STV added are in $\mathrm{mg}$. In spectrophotometric methods the same are in $\mu \mathrm{g}$.

for stavudine and are superior to the existing HPLC and UV-spectrophotometric methods. They rely on the use of simple and cheap chemicals, and inexpensive techniques but provide a sensitivity comparable to that achieved by sophisticated and expensive technique like HPLC. These advantages coupled with good accuracy and precision make the methods highly suitable for routine use in laboratories as a part of industrial quality control.

\section{ACKNOWLEDGMENTS}

The authors express their gratitude to Cipla India Ltd., Bangalore for supply of pure stavudine as gift. Three of the authors (VRK, BCS and URA) thank the authorities of the University of Mysore, Mysore, for facilities. VRK is grateful to the Principal Secretary, Department of Health and Family Welfare, Government of Karnataka, Bangalore, for permission.

\section{RESUMO}

Este trabalho descreve quatro métodos rápidos e sensíveis para a determinação de estavudina (STV) na matéria-prima ou em produtos formulados. Soluções aquosas de STV podem ser tituladas tratando-as com excesso de bromato-brometo em meio ácido clorídrico, seguido da determinação iodimétrica de bromo em excesso. Métodos espectrofotométricos também envolvem a adição de excesso de bromato-brometo à amostra, seguida da determinação de bromo residual por adição de uma quantidade fixa de alaranjado de metila, índigo-carmim ou azul de timol, e de medidas de absorbância nos comprimentos de onda apropriados: 520, 610 ou $550 \mathrm{~nm}$. Em todos os métodos, a quantidade de bromato consumida corresponde à quantidade de STV e os resultados da sua aplicação à determinação de STV em comprimidos e cápsulas são satisfatórios.

Palavras-chave: determinação de estavudina, titulometria, espectrofotometria, bromato-brometo, corantes, fármacos.

\section{REFERENCES}

Bazy V, Morin P, Courbe P, Leleu G and AgroFOGLIO L. 2005. Simultaneous analysis of several antiretroviral nucleosides in rat-plasma by high performance liquid chromatography with uv using acetic acid/hydroxylamine buffer. J Chromatogr B 821: 132-143.

Compain S, Schlemmer D, Levi M, Pruvost A, GouJARD C, GRASSI J AND BENECH H. 2005. Development and validation of a liquid chromatographic/tandem mass spectrometric assay for the quantitation of nucleoside HIV reverse transcriptase inhibitors in biological matrices. J Mass Spectro 40: 9-18.

Contreras J, Gonzalez H Ma, Menendez R and LOPEZ M. 2004. Development and validation of a reversed phase liquid chromatographic method for the anal- 
ysis of $\mathrm{D}$ and $\mathrm{T}$ (stavudine) in rat plasma. J Chromatogr B 801: 199-203.

DJURdJEVIC P, LABAN A, MARKovic S AND JELIKIKSTANKOV M. 2004. Chromometric optimization of a RP-HPLC method for the simultaneous analysis of abacavir, lamivudine and zidovudine in tablets. Anal Lett 37: 2649-2667.

Dunge A, Sharda N, Singh B and Singh S. 2005. Establishment of inherent stability of stavudine and development of a validated stability-indicating HPLC assay method. J Pharm Biomed Anal 37: 1115-1119.

FAN B AND STEWART JT. 2002. Determination of stavudine/didanosine/saquinavir and stavudine/didanosine/efavirenz in human serum by micellar electrokinetic chromatography. J Liq Chromatogr Rel Technol 25: 937-947.

Fan B. Bartlett MG and Stewart JT. 2002. Determination of lamivudine/stavudine/efavirenz in human serum using liquid chromatography/electrospray tandem mass spectrometry with ionization polarity switch. Biomed Chromatogr 16: 383-389.

Huang Y, Zurlinden E, Lin E, Li X, Tokumoto J, Golden J, Murr A, Engstorm J and Conte J. 2004. Liquid chromatographic-tandem mass spectrometric assay for the simultaneous determination of didanosine and stavudine in human plasma, Branchoalveolar lavage fluid, alveolar cells, periphera blood mononuclear cells, seminal plasma, cerebrospinal fluid and tonsil tissue. J Chromatogr B 799: 51-61.

Kaul N, Agarawal H, Paradkar AR and Mahadik KR. 2005. The ICH guideline in practice: Stress degradation studies on stavudine and development of a validated specific stability-indicating HPTLC assay method. J Chromatogr Sci 43: 4016-415.

PAi NR AND Desai AS. 2003. Simultaneous estimation of some antiretroviral drugs from tablets by reverse phase HPLC method. Indian Drugs 40: 111-114.

Pereira EA, Mkke GA and Tavares MFM. 2005. Determination of antiretroviral agents in human serum by capillary electrophoresis. J Chromatogr A 1091: 169176.

Raices RSL, Salvadori MC, Estrela RCE, Deaquin Neto FR and Squrez-Kurtz G. 2003. Determination of stavudine in human serum by on-line solid-phase extraction coupled to HPLC with electrospray ionization tandem mass spectrometry: application to a bioequivalence study. Rapid commun Mass Spectro 17: 1611-1618.

REZK NL, TIDWELl RR, Richard R AND KashubA ADM. 2003. Simultaneous determination of six HIV nucleoside analogue reverse transcriptase inhibitors and nevirapine by HPLC with ultraviolet absorbance detection. J Chromatogr B 791: 137-147.

Sablon M, Contreras J, Diaz O, Perez R, Velez H AND RodrigueZ-TANTY C. 2004. Quantification of an antiviral drug (d 4T) by an HPLC procedure. Acta Pharma Bona 23: 81-88.

SANKAR DG, REDDY MVVN, KUMAR JMR AND MURTHY TK. 2002a. uv spectrophotometric determination of some anti-HIV drugs. Asian J Chem 14: 433-436.

SANKAR DG, REDDY MVVN, KUMAR JMR AND MURTHY TK. 2002b. Spectrophotometric determination of lamivudine and stavudine. Indian J Pharm Sci 64: 504-506.

SARMa CSN, SASTRI CK AND SASTRy CSP. 2002a. Simple oxidimetric methods for determination of stavudine or lamivudine. Asian J Chem 14: 683-690.

SARMa CSN, SAStri CK And SASTRY CSP. 2002b. Determination of stavudine and lamivudine by visible spectrophotometry. Acta Ciencia Indica Chem 28: 221-225.

SoLDIN SJ. 2004. Anti-retroviral analysis by mass spectrometry. PCT Int Appl Patent No. Wo 2004089182.

The Merck Index. 1996. 12th ed., Merck and Co. Inc, White House Station. NJ, p. 1502.

The United States Pharmacopoeia. 2006. United States Pharamcopoeial Convention Inc., Rockville, p. 2005-2007.

Tran Tt, Robbins BL, Pinkerton FH, Ferrua B, GRASSI J AND FRIDLAND A. 2003. A new sensitive cartridge-RIA method for determination of stavudine (D4T) triphosphate in human cells in vivo. Antiviral Res 58: 125-129.

VerWeiJ-VAn Wissen CPWGM, Aarnoutse RE AND BURGER DM. 2005. Simultaneous determination of the HIV nucleoside analogue reverse transcriptase inhibitors lamivudine, didanosine, stavudine, zidovudine and abacavir in human plasma by reverse phase HPLC. J Chromatogr B 816: 121-129.

Volosov A, Alexander C, Ting L and Soldin SJ. 2002, Simple rapid method for quantification of antiretrovirals by liquid chromatography-tandem mass spectrometry. Clin Biochem 35: 99-103.

WANKhEde SB, Guptha KR AND WAdOdKAR SG. 2005. Simultaneous high performance thin layer chromatographic estimation of lamivudine and stavudine in tablet dosage forms. Indian J Pharm Sci 67: 96-97. 
Wiesner JL, SUTHERLAND FCW, SMit MJ, VAN ESSEN GH, HundT HKL, SwART KJ AND HundT AF. 2002. Sensitive and rapid liquid-chromatography-tandem mass spectrometry method for the determination of stavudine in human plasma. J Chromatogr B 773: 129-134.

ZHANG M AND CEN J. 2003. Determination of stavudine and its related substances by HPLC. Zhongguo Yiyao Gongye Zazhi 34: 402-403.
International Conference on Hormonisation of Technical Requirements for Registration of Pharmaceuticals for $\mathrm{Hu}-$ man Use, ICH Harmonised Tripartite Guideline, Validation of Analytical Procedures: Text and Methodology Q2 (R1), Complementary Guideline on Methodology dated 06 November 1996, incorporated in November 2005, London. 